\title{
Produktivitas Ayam Pedaging Pola Kemitraan di Kabupaten Lombok Barat
}

\section{Productivity of Broilers in Partnership Farm System in West Lombok District}

\author{
D. K. Purnamasari,* Syamsuhaidi, K.G Wiryawan, Erwan, Sumiati, W. Zohriana, dan Y. Arifin \\ Fakultas Peternakan Universitas Mataram \\ Jl. Majapahit No. 62 Mataram-NTB. Tlp/Fax: (0370) 633603/640592 \\ *Corresponding Author Email: emmadkp03@gmail.com
}

Manuscript received: 08-7-2021. Accepted: 28-10-2021

\begin{abstract}
ABSTRAK
Penelitian bertujuan untuk mengetahui tingkat produktifitas ayam pedaging pada sistim peternakan kemitraan kaitannya dengan kualitas pakan perusahaan mitra yang diberikan. Penelitian dilakukan dalam 2 (dua) tahapan; Tahap I. Survei sistim pemberian pakan peternakan sistim kemitraan di Lombok Barat. Parameter yang diamati meliputi: jenis pakan komplit yang diberikan, jumlah dan frekuensi pemberian pakan, bobot panen, dan FCR. Tahap II. Evaluasi kandungan nutrisi pakan komplit yang digunakan pada peternakan sistim kemitraan. Parameter yang diamati meliputi: kadar air, kadar abu, protein kasar, lemak kasar, dan serat kasar. Data yang diperoleh ditabulasi dan dilakukan pembahasan secara deskriptif. Berdasarkan hasil survei terdapat 8 jenis perusahaan kemitraan di Lombok Barat, yaitu PT. Mitra Sinar Jaya, PT. Baling-baling Bambu, PT. Samsung, PT. Dinamika Megatama Citra, PT. Bagus Sukses Sejahtera, PT. Fidaus Mitra Sejahtera, PT. Karya Unggas Sejahtera dan PT. Panca Artha Lombok, dan 6 jenis pakan komplit yang digunakan, yaitu S12, GM-PS, GM 1 EJ, Malindo, Wonokoyo, HD BR1 161. Rata-rata konsumsi ayam 3,24 $\mathrm{kg} / \mathrm{ekor} /$ periode, dengan rata-rata PBB 2,10 kg/ekor/periode, serta rata-rata FCR 1,54. Berdasarkan hasil evaluasi kandungan nutrisi, terdapat ketidaksesuaian kandungan nutrisi terutama kadar protein kasar yang lebih rendah $(0,01 \%)$ dengan yang tertera di leaflet pada pakan starter dari perusahaan Wonokoyo. Kesimpulan dari penelitian ini adalah secara umum kualitas pakan komplit yang digunakan perusahaan mitra masih sesuai standar kualitas pakan berdasarkan SNI dan produktifitas ayam pedaging yang dihasilkan memenuhi standar perusahaan.
\end{abstract}

Kata kunci: Nutrisi; Pakan Komplit; Konsumsi; Bobot Panen; Konversi Pakan

\begin{abstract}
This study aims to determine the level of productivity of broilers in the partnership farm system in relation to the quality of feed provided by partner companies. The research was conducted in 2 (two) stages; Phase I. Survey of feeding system in partnership system of broiler farming in West Lombok. The parameters observed included: type of feed offered, the amount provided and frequency of feeding, harvest weight, and FCR. Phase II. Evaluation of the chemical composition of the diet used in partnership broiler farming system. The parameters observed included: the moisture, ash, protein, fat and fiber. The data obtained were tabulated and discussed descriptively. Based on the survey
\end{abstract}


results, there are 8 partnership companies, namely PT. MSJ, PT. BBB, PT. Samsung, PT. DMC, PT. BSS, PT. FMS, PT. KUS and PT. PAL, and 6 types of feed used, namely S12, GM-PS, GM 1 EJ, Malindo, Wonokoyo, HD BR1 161. Average feed consumption is $3.24 \mathrm{~kg} /$ head / period, with weight gain of $2.10 \mathrm{~kg} /$ head / period, with the FCR value of 1.54. Based on the results of the evaluation of the nutritional content, there is a mismatch, especially the protein content which is lower $(0.01 \%)$ as shown in the leaflet of the starter feed from Wonokoyo company. The conclusion of this study is that in general, the complete feed quality used is in accordance with the SNI based feed quality standards and the broiler productivity produced on partner farms meets the company standards.

Keyword: Nutritional; Complete Feed; Consumption; Weight Gain; Feed Conversion

\section{PENDAHULUAN}

Berdasarkan hasil penelitian Purnamasari, D.K., dkk. (2016) yang melakukan evaluasi terhadap kualitas pakan komplit dan konsentrat unggas yang diperdagangkan di Kota Mataram, bahwa terdapat 5 jenis pakan kosentrat dan 13 jenis pakan komplit yang merupakan hasil produksi perusahaan-perusahaan pakan nasional Indonesia. Lebih lanjut dihasilkan bahwa rata-rata pakan mengalami penurunan kadar air sebesar $4.43 \%$, dimana hasil analisis laboratorium (7.7-9.93\%) dan yang tertera di leaflet (12-13\%). Demikian juga dengan pakan konsentrat terjadi penurunan kadar air sebesar 6.43\%. Kadar protein pakan komplit juga mengalami penurunan sebesar $0.46 \%$ dan pakan konsentrat sebesar $0.63 \%$. Kadar lemak pun mengalami penurunan sebesar $0.95 \%$ pada pakan komplit dan $0.45 \%$ pada pakan konsentrat.

Ketidaksesuaian kandungan nutrisi hasil analisis dengan yang tertera di leaflet hasil penelitian tahun 2016 ternyata dirasakan oleh peternak saat ini, dimana terjadi penurunan produktifitas ternak khususnya pada peternakan mitra, sehingga peternak mengalami kerugian. Ketidaksesuaian kandungan nutrisi yang tertera di label dengan kandungan yang sebenarnya mengakibatkan performan yang dihasilkan tidak sesuai dengan harapan peternak. Adapun bentuk kerugian yang dialami oleh peternak adalah : 1). Pertumbuhan ayam yang tidak sesuai atau ayam kerdil, sebagai contoh pada ayam potong pada umur 14 hari seharusnya mencapai bobot standar $540 \mathrm{~g}$, pertumbuhan yang diperoleh peternak adalah $430 \mathrm{~g}$ yang setara dengan BB umur 12 hari. Hal ini menyebabkan peternak menderita kerugian dari segi waktu pemeliharaan yang lebih lama untuk mendapatkan bobot badan yang sesuai untuk di panen, 2). Selain pertumbuhan yang lebih lambat, kerugian lain yang diderita peternak adalah FCR yang lebih besar atau konversi pakan menjadi daging lebih tinggi (Rozy, 2016 komunikasi pribadi dalam Purnamasari, D.K., dkk., 2016).

Lebih lanjut dinyatakan bila dihitung secara ekonomi peternak mengalami pemborosan biaya dalam bentuk: 1). Harga pakan yang mahal karena ketidak sesuaian antara nilai protein dan harga jual pakan, 2). Setiap $1 \mathrm{~kg}$ bobot ayam peternak mengalami kehilangan berat sebasar $50-100 \mathrm{~g}$ atau per ekor ayamnya sebesar $100-200 \mathrm{~g}$, dengan asumsi bobot panen $2.0 \mathrm{~kg}$. Bila harga bobot hidup untuk setiap $1 \mathrm{~kg}$ ayam sebesar Rp. 20.000 maka peternak mengalami kerugian sebesar Rp. 200 - 400 per ekor ayam. Bila populasi 1000 ekor setara dengan Rp. 200.000 - 400.000, pada populasi 10.000 ekor setara dengan 2.000.000 - 4.000.000, bila dikalkulasikan dengan total populasi di masyarakat yang mencapai ratusan ribu ekor sudah 
pasti dapat diprediksi kerugian masyarakat peternak yang sangat besar hingga mencapai ratusan juta rupiah.

Penelitian selanjutnya yang perlu dilakukan. adalah menelusuri performan produktifitas ayam pedaging yang diberi pakan komplit. Hal ini perlu dilakukan karena kunci kesuksesan dalam usaha peternakan ayam pedaging dipengaruhi oleh tiga faktor utama yaitu penyediaan bibit unggul, pemenuhan kebutuhan pakan, dan managemen pemeliharaan yang baik. Ketiga faktor produksi tersebut merupakan satu kesatuan sistem yang apabila salah satu faktor terabaikan atau kurang mendapat perhatian maka penanganan terhadap faktor yang lain tidak dapat memberikan hasil yang maksimal (Anggitasari, S., dkk., 2016).

Anggitasari, S., dkk. (2016) telah mengevaluasi beberapa jenis pakan komersial dan pengaruhnya terhadap kinerja produksi kuantitatif dan kualitatif ayam pedaging, dihasilkan dari 4 jenis pakan komersial yang dianalisis mengandung protein kasar sebesar 20.02-22.68\% masih sesuai dengan standar yang dikeluarkan oleh Badan Satandar Nasional yaitu untuk ayam pedaging protein pakan minimal 19\%. Lebih lanjut dilaporkan bahwa perbedaan pakan komersial tidak mempengaruhi konsumsi pakan ayam pedaging, sedangkan bobot badan panen tertinggi sebesar $2.016 \mathrm{~g}$ /ekor dan pakan bentuk pelet memiliki konversi pakan terbaik yaitu 1.8. Bahri dan Rusdi (2008) juga melakukan evaluasi energi metabolis pakan lokal yaitu tepung jerami bawang merah, tepung ampas tahu dan tepung kulit pisang pada ayam petelur secara biologis. Resnawati (2006) melakukan penelitian dengan menggunakan berbagai bahan pakan dan disuplementasi dengan cacing pada ayam pedaging untuk mengetahui retensi nitrogen dan energi metabolis pakan.

Usaha peternakan ayam pedaging di Pulau Lombok terdapat dua sistem yaitu sistem kemitraan dan sistem mandiri. Usaha peternakan sistem kemitraan mendominasi di Pulau Lombok. Terdapat 14 perusahaan kemitraan yang mendominasi yaitu: perusahaan PT. Mitra Sinar Sejahtera (MSJ), PT. Ciomas Adisatwa (CA), PT. Anudrah Kartika Agro (AKA), PT. Duta Mulia Cakrawala (DMC), PT. Andalan Ternak Makmur (ATM), PT. Bagus Sukses Sejahtera (BSS), PT. Baling-Baling Bambu (BBB), PT. Bintang Terang Tunggal (BTT), PT. Mitra Rakyat Sukses (MRS), dan PT. Rinjani Mitra Sejahtera (RMS). Pada sistem ini, semua kebutuhan dalam menjalani usaha disediakan oleh perusahaan mitra kecuali perkandangan dan lahan yang harus disediakan oleh peternak. Semua hasil panen pada sistem kemitraan akan dibeli oleh perusahaan mitra dan peternak akan memperoleh keuntungan dari selisih hasil penjualan dengan biaya produksi. Selain kemitraan adalah usaha mandiri yang dikembangkan secara mandiri oleh peternak, hanya saja usaha mandiri masih dalam skala kecil karena keterbatasan kepemilikan modal dan penjualan hasil panen.

Beberapa keuntungan beternak ayam pedaging sistem kemitraan yang diperoleh oleh peternak yaitu: harga ayam bisa lebih tinggi dibandingkan harga pasar, sarana produksi peternakan (sapronak) ditanggung perusahaan kemitraan, pemasaran dilakukan bersama-sama. Namun terdapat juga kerugian beternak sistem kemitraan, yaitu: ketidakjujuran perusahaan tentang biaya pasti yang harus ditanggung, sistem bagi hasil yang tidak merata, adanya potongan harga jika ada ayam sakit, sehingga bila musim dan iklim tidak menentu maka akan semakin banyak ayam yang sakit dan mati sehingga merugikan peternak (Izkey, 2018). 
Berdasarkan hasil penelitian Saguni, A.W. (2010) yang meneliti analisis pendapatan peternak ayam potong sistem kemitraan di kecamatan Turen kabupaten Malang, ternyata menghasilkan bahwa usaha ayam pedaging pola kemitraan masih kurang menguntungkan, dimana nilai BCR sebesar 1.09 setiap periode pemeliharaan dan nilai Pay Back Periode adalah 14.4, sehingga disarankan untuk melakukan perbaikan managemen pemeliharaan.

Kesuksesan usaha kemitraanpun berfluktuasi, terkadang peternak memperoleh keuntungan dan bonus dari perusahaan, tapi terkadang pula mengalami kerugian. Banyak faktor yang mempengaruhi, diantaranya: masalah penyakit, tingkat konsumsi produk hewani yang berfluktuasi yang mempengaruhi harga bobot panen, nilai tukar rupiah terhadap dolar yang mempengaruhi harga pakan, managemen pemeliharaan ayam oleh peternak, serta yang tidak kalah pengaruhnya adalah kualitas pakan yang dihasilkan perusahaan mitra, yang kemungkinan diduga mengalami penurunan kualitas. Adventa, E. (2019) menyatakan untuk meningkatkan produktifitas ayam pedaging saat ini PT Japfa Comfeed Indonesia Tbk menyarankan adanya inovasi dalam pemeliharaan ayam yaitu salah satunya dengan menggunakan closed house farm atau peternakan tertutup. Metode ini memungkinkan peternak meningkatkan berat ayam secara signifikan tanpa harus memberi pakan tambahan, karena ayam dipelihara dalam kandang tertutup dengan suhu yang sudah diatur sesuai kebutuhan untuk meminimalisir gangguan dari luar, sehingga ayam bisa tenang dan berat badannya otomatis dapat naik.

Pengontrolan usaha secara kontinyu baik dari pemerintah daerah maupun dari akademisi untuk melindungi peternak lokal agar tidak mengalami kerugian harus dilakukan, dengan mengevaluasi kualitas pakan yang diberikan dihubungkan dengan performan produktifitas ayam pedaging yang dihasilkan.

\section{BAHAN DAN METODE}

Penelitian 'Produktivitas Ayam Pedaging Pola Kemitraan di Kabupaten Lombok Barat' dilakukan dalam 2 tahapan, yaitu :

Tahap I. Survei sistim pemberian pakan pada peternakan ayam pedaging sistim kemitraan di Kabupaten Lombok Barat.

Penelitian dilakukan dengan mendata jenis pakan, jumlah pemberian pakan, frekuensi pemberian pakan, bobot panen, dan FCR selama 3 periode pemeliharaan. Data kandungan nutrien pakan yang digunakan dan yang tercantum pada leaflet dicatat, kemudian sampel pakan sebanyak $100 \mathrm{~g}$ diambil dan di masukkan pada kantung sampel yang telah diberi label. Sampel pakan yang terkumpul dibawa ke Laboratorium untuk dianalisis kandungan makro nutrien melalui metode analisis proksimat. Parameter pada tahap I. adalah jumlah konsumsi pakan per hari per ekor per periode, bobot panen, FCR, dan kesesuaian kandungan nutrien pakan dengan yang tertera di leaflet. Data yang telah terkumpul dilakukan pembahasan secara deskriptif dengan membandingkan berdasarkan standar yang telah ditentukan oleh perusahaan mitra.

Tahap II. Evaluasi kualitas pakan komplit unggas yang ada di peternakan mitra di Kabupaten Lombok Barat. 
Dilakukan analisis sampel pakan yang telah terkumpul untuk mengetahui kandungan nutrien melalui prosedur Proximate Analysis (AOAC, 1990). Adapun parameter yang akan diamati dalam tahap ini meliputi: kadar air, kadar abu, protein kasar, lemak kasar, dan serat kasar. Data yang terkumpul dilakukan pembahasan tingkat kesesuaian kandungan nutrien pakan hasil analisis laboratorium dengan yang tertera di leaflet dan standar kandungan nutrien dalam pakan berdasarkan SNI 2015.

\section{Materi Penelitian}

Materi penelitian terdiri dari peternak ayam pedaging sistim kemitraan yang terdapat di wilayah Lombok Barat sejumlah 10, seperangkat peralatan wawancara, plastik sampel pakan beserta label nama pakan, sampel pakan, serta seperangkat peralatan dan bahan analisis kandungan nutrien pakan dengan metode Proximate Analysis (AOAC, 1990).

\section{Analisis Data}

Semua data yang terkumpul pada Tahap I dan II, ditabulasi dan dilakukan pembahasan secara deskriptif dengan membandingkan semua parameter berdasarkan standar menurut literatur atau standar perusahaan mitra..

\section{HASIL DAN PEMBAHASAN Jenis Pakan Yang Digunakan Pada Peternakan Mitra}

Hasil survei menunjukkan bahwa terdapat 8 (delapan) perusahaan kemitraan ayam pedaging di Kabupaten Lombok Barat, yaitu PT. Mitra Sinar Jaya (MSJ), PT. Baling Baling Bambu (BBB), PT. Samsung, PT. Dinamika Megatama Citra (DMC), PT. Bagus Sukses Sejahtera (BSS), PT. Fidaus Mitra Sejahtera (FMS), PT. Karya Unggas Sejahtera (KUS) dan PT. Panca Artha Lombok (PAL). Jumlah peternak mitra masing-masing perusahaan hanya PT. Mitra Sinar Jaya yang terdapat datanya di Instansi Pemerintah Daerah yaitu sebanyak 21 peternak, sedangkan perusahaan lainnya tidak terdapat datanya karena merupakan rahasia perusahaan. PT. Mitra Sinar Jaya adalah perusahaan mitra ayam pedaging terbesar di Pulau Lombok merupakan salah satu anak perusahaan PT Charoen Pokphan Indonesia yang membudidayakan ayam ras pedaging untuk memenuhi kebutuhan konsumen akan ayam dan juga memasarkan telur ayam. Berdasarkan hasil penelitian Antara, M. dan B. Aji, (2020), bahwa PT Mitra Sinar Jaya memiliki kekuatan yaitu pada jaminan kualitas dari ayam broiler, profesionalisme karyawan, dan pelayanan terhadap konsumen. Strategi pemasaran utama PT Mitra Sinar Jaya yaitu market penetration, market development, dan product development atau strategi terintegrasi seperti backward integration, forward integration, dan horizontal integration.

Pakan komplit merupakan jenis pakan yang cukup mengandung nutrien untuk hewan dalam tingkat fisiologis tertentu yang dibentuk dan diberikan sebagai satu-satunya pakan yang mampu memenuhi kehidupan hidup pokok dan produksi tanpa tambahan lain, kecuali air. Medion (2014), menyatakan bahwa pakan komplit adalah pakan yang diberikan kepada unggas, dimana kandungan nutrisinya telah disusun lengkap sesuai dengan kebutuhan unggas. Pakan komplit diberikan langsung tanpa mencampur dengan bahan pakan lainnya, sedangkan 
pakan konsentrat, merupakan pakan padat nutrisi buatan pabrik, dimana pemberiannya harus dicampur terlebih dahulu dengan jagung giling, bekatul atau dedak.

Peternak mitra menggunakan pakan komplit yang disuplai oleh perusahaan mitra. Terdapat 6 (enam) jenis pakan komplit yang digunakan seperti tersaji pada Tabel 1.

Tabel 1. Data Peternak Mitra dan Jenis Pakan Yang Digunakan

\begin{tabular}{ccc}
\hline Peternak Mitra & \multicolumn{2}{c}{ Jenis Pakan Yang Digunakan } \\
\cline { 2 - 3 } & Starter & Finisher \\
\hline 1 & S10 dan S11 & S12 \\
2 & GM 1 EJ & GM 2 \\
3 & GM 1 EJ & GM 2 \\
4 & GM - PS & GM - PS \\
5 & GM - PS & GM - PS \\
6 & GM - PS & GM - PS \\
7 & Malindo & SB 21 \\
8 & Wonokoyo & Wonokoyo \\
9 & HD BR1 161 & HDBR1 161 \\
10 & Malindo & Malindo \\
\hline
\end{tabular}

Sumber: Data Primer tahun 2020

Berdasarkan data pada Tabel 1 dan berdasarkan hasil wawancara, peternak terkadang menggunakan pakan 1 jenis mulai fase starter hingga finisher, ada juga yang menggunakan 2 jenis untuk fase starter dan finisher, dan satu peternak menggunakan 3 jenis yaitu untuk fase starter, grower, dan finisher. Hal ini di dasarkan pada ketersediaan pakan yang disuplai oleh perusahaan mitra yang seringkali dipengaruhi oleh kondisi tertentu, seperti pada saat penelitian dilakukan, kondisi dalam keadaan pandemi Covid 19. Pandemi Covid 19 menyebabkan banyak peternak mitra yang tidak beroperasi, dan kalaupun ada peternak yang masih beroperasi jumlah ternak dan pakan dibatasi dikarenakan permintaan yang semakin menurun, hampir seluruh hotel dan restauran tutup dan kemampuan daya beli masyarakat juga menurun.

\section{Performan Ayam Pedaging}

Performan merupakan sifat-sifat yang dapat diamati atau dapat diukur dari konsumsi pakan, bobot panen, dan konversi pakan. Adapun hasil penelitian yang mencakup tentang performan ayam pedaging yang ada di Kabupaten Lombok Barat disajikan pada Tabel 2.

Tabel 2. Performan produktifitas ayam pedaging pada peternakan mitra di Lombok Barat

\begin{tabular}{ccccccc}
\hline \multirow{2}{*}{$\begin{array}{c}\text { Peternak } \\
\text { Mitra }\end{array}$} & $\begin{array}{c}\text { Konsumsi } \\
\text { Pakan } \\
\text { (kg/e/periode) }\end{array}$ & $\begin{array}{c}\text { Bobot } \\
\text { Panen } \\
\text { (kg/ekor) }\end{array}$ & FCR & $\begin{array}{c}\text { Konsumsi } \\
\text { Pakan } \\
\text { (kg/e/periode) }\end{array}$ & $\begin{array}{c}\text { Bobot } \\
\text { Panen } \\
(\text { kg/ekor })\end{array}$ & FCR \\
\hline 1 & 2,91 & 2,00 & 1,46 & 4,27 & 2,40 & 1,76 \\
2 & 4,17 & 2,20 & 1,90 & 3,88 & 2,30 & 1,71 \\
3 & 3,25 & 2,00 & 1,63 & 3,01 & 1,90 & 1,62 \\
4 & 3,21 & 2,00 & 1,61 & 3,69 & 2,20 & 1,69 \\
5 & 3,20 & 2,10 & 1,52 & 3,17 & 1,90 & 1,64 \\
6 & 3,44 & 2,20 & 1,56 & 3,17 & 1,90 & 1,64 \\
7 & 2,96 & 2,10 & 1,41 & 3,01 & 1,90 & 1,62 \\
8 & 3,19 & 2,20 & 1,45 & 3,01 & 1,90 & 1,62 \\
\hline
\end{tabular}




\begin{tabular}{ccccccc}
\hline 9 & 2,90 & 2,00 & 1,45 & 3,01 & 1,90 & 1,53 \\
10 & 3,18 & 2,20 & 1,45 & 3,51 & 2,10 & 1,67 \\
\hline Rata-rata & $3,24 \pm 0,37$ & $2,10 \pm 0,09$ & $1,54 \pm 0,15$ & $3,37 \pm 0,44$ & $2.04 \pm 0,20$ & $1,65 \pm 0,05$ \\
\hline \multicolumn{7}{c}{ Sumber: * Japfa Comfeed Indonesia (2008) dalam Direktorat Pembinaan SMK Kemendikbud } \\
RI (2013). Standar didasarkan pada umur panen.
\end{tabular}

\section{Konsumsi Pakan}

Tabel 2 menunjukkan bahwa konsumsi pakan pada 10 peternakan kemitraan, bervariasi berkisar 2,90-4,17 kg/ekor/periode atau rata-rata 3,24 kg/ekor/periode. Tingkat konsumsi pakan ayam pada semua peternakan kemitraan masih memenuhi standar konsumsi pakan berdasarkan standar Japfa Comfeed Indonesia yaitu rata-rata sebesar 3,37 $\mathrm{kg}$ /ekor/periode. Standar konsumsi didasarkan pada umur panen dari masing-masing peternakan yang berbeda-beda. Umur panen berkisar dari 27-42 hari dengan rata-rata $36,30 \pm 4,06$. Perbedaan umur panen ini disebabkan banyak faktor dan kondisi yang terjadi pada saat penelitian. Konsumsi pakan pada kandang peternak 2 cukup tinggi sebesar 4,17 $\mathrm{kg} / \mathrm{ekor} /$ periode, dibandingkan dengan nilai standar Japfa Comfeed Indonesia yaitu sebesar $3,88 \mathrm{~kg} / \mathrm{ekor} /$ periode, dikarenakan masa pemeliharaan yang lebih lama yaitu 40 hari. Selain itu lokasi peternakan ke-2 berada pada kondisi lingkungan yang sejuk dan dingin dengan temperatur rata-rata $22,2^{\circ} \mathrm{C}$ dan kelembapan udara $78 \%$ sehingga diduga meningkatkan konsumsi pakan. Sebaliknya pada lokasi yang berbeda, peternakan ke-1 memiliki standar konsumsi yang tinggi yaitu 4,27 kg/ekor/periode, namun ternak mengkonsumsi pakan jauh lebih rendah dari standar yaitu $2,91 \mathrm{~kg} / \mathrm{ekor} /$ periode.

Konsumsi pakan, konsumsi protein dan energi ayam pedaging dipengaruhi oleh suhu lingkungan, dimana semakin tinggi suhu lingkungan maka ternak akan banyak minum dari pada makan. Gunawan dan Sihombing (2004) menambahkan bahwa pada suhu lingkungan tinggi, jumlah penurunan konsumsi pakan bervariasi, tergantung dari strain ayam, lamanya cekaman panas, tingkat produksi, berat telur, dan kandungan energi metabolisme dari pakan yang diberikan. Perbedaan konsumsi pakan ayam pedaging disebabkan oleh beberapa faktor di antaranya, yaitu sistem perkandangan dan temperatur lingkungan. Wahyu (1998) menyatakan bahwa konsumsi pakan yang dikonsumsi dipengaruhi oleh beberapa faktor seperti bangsa ayam, tingkat produksi, temperatur lingkungan, sistem kandang, periode pertumbuhan dan adanya penyakit. Fatmaningsih, dkk. (2016) menambahkan bahwa konsumsi pakan dipengaruhi oleh kemampuan individu dalam mencerna makanan serta kondisi lingkungan pada kandang. Rahardjo (2018) menyatakan bahwa jumlah pakan yang diberikan sangat bergantung dari jenis ayam yang dipelihara, sistem pemeliharaan,dan tujuan produksi, disamping itu juga dipengaruhi oleh beberapa faktor yang berkaitan dengan genetik dan lingkungan peternakan. Sistem pemberian pakan ayam pedaging pada masing-masing peternak yaitu rata-rata diberikan secara adlibitum (tidak dibatasi) dengan frekuensi pemberian pakan 2 kali sehari pada jam 07.00 WITA dan 17.30 WITA. Rasyaf (1993) menyatakan bahwa frekuensi pemberian pakan 2-3 kali sehari akan menguntungkan secara teknis maupun ekonomis dalam pengelolaan pakan ayam. Pemberian pakan secara adlibitum ditujukan 
mempercepat pertumbuhan ayam, dengan jumlah pemberian pakan terus bertambah mengikuti pertambahan umur ayam (Fadilah, 2007).

\section{Bobot Panen}

Konsumsi dan kandungan nutrisi pakan merupakan salah satu faktor penting dalam menentukan produktivitas dan pertumbuhan ayam pedaging. Tingkat keberhasilan dalam pemeliharaan ayam pedaging terlihat dari bobot panen ayam yang akan dijual. Berdasarkan data bobot panen pada Tabel 2 menunjukkan bahwa rata-rata bobot panen ayam pedaging sebesar 2,10 kg/ekor/periode. Rata-rata bobot panen yang diperoleh dari penelitian ini lebih tinggi dibandingkan dengan rata-rata bobot panen berdasarkan standar Japfa Comfeed Indonesia yaitu sebesar $1,96 \mathrm{~kg} /$ ekor/periode. Salah satu faktor yang mempengaruhi bobot panen adalah faktor genetik. Amrullah (2004) menyatakan bahwa performa dapat dilihat melalui perkembangan dan pertumbuhan ayam yaitu diketahui dengan cara melakukan penimbangan berat tubuh ayam setiap minggu sehingga akan diketahui rata-rata berat tubuh hariannya. Ayam yang memiliki fisik yang baik menandakan tingkat pertumbuhannya bagus dan akan menghasilkan performa yang baik.

Selain faktor genetik, petumbuhan bobot panen pada ayam pedaging juga dipengaruhi oleh beberapa faktor yaitu konsumsi pakan, kandungan nutrisi pakan, manajemen pemeliharaan dan lingkungan. Bobot panen ayam pada peternakan ke-1 jauh lebih rendah dari standar, hal ini dikarenakan konsumsi pakan yang juga rendah. Widodo (2009) menyatakan bahwa pakan yang dikonsumsi oleh ternak unggas sangat menentukan pertambahan bobot badan sehingga berpengaruh terhadap efesiensi suatu usaha peternakan. Anggitasari, S. dkk (2016) menambahkan bahwa konsumsi pakan juga dipengaruhi oleh temperatur lingkungan, kesehatan ayam, perkandangan, wadah pakan, dan kandungan zat makanan dalam pakan. Pakan yang mengandung protein lebih tinggi dari lainnya cenderung memberikan bobot badan yang lebih tinggi, sedangkan pakan yang mengandung protein rendah dan dikonsumsi dalam jumlah sedikit dapat menyebabkan terjadinya defisiensi atau ketidakseimbangan asam amino yang menghambat pertumbuhan.

\section{Konversi Pakan}

Konversi pakan adalah pakan yang dikonsumsi untuk menghasilkan satu kilogram daging. Konversi pakan dapat diketahui dengan cara menghitung rasio antara konsumsi pakan dengan pertambahan bobot badan ayam. Semakin kecil jumlah pakan yang dibutuhkan untuk menghasilkan pertambahan bobot badan ayam, berarti semakin efesien pemberian pakan tersebut (Tamalluddin, 2014).

Data pada Tabel 2 menunjukkan bahwa rata-rata konversi pakan yang diperoleh dari penelitian ini sebesar 1.54. Nilai ini lebih rendah dengan nilai standar konversi pakan yang ditetapkan oleh Japfa Comfeed Indonesia yaitu sebesar 1,65. Namun konversi pakan pada kandang peternak 2 cukup tinggi sebesar 1,90 dibandingkan nilai standar konversi pakan yang ditetapkan Japfa Comfeed Indonesia yaitu sebesar 1,71. Faktor yang mempengaruhi konversi pakan adalah genetik, kualitas pakan, temperatur, bahan baku zat makanan yang digunakan 
dalam pakan (Fitro, dkk, 2015). Menurut Fatmaningsih dkk. (2016) bahwa konversi pakan yang efesien menunjukkan bahwa kulitas dan kuantitas pakan yang digunakan terjamin baik sehingga tingkat konsumsi pakan ayam pedaging jadi baik dan berdampak pada pertambahan bobot badan yang optimal. Nilai konversi pakan yang tinggi menunjukkan bahwa efesiensi pakan kurang baik, sehingga pertambahan bobot badan ayam tidak sesuai dengan jumlah pakan yang dikonsumsi, sedangkan konversi pakan yang rendah menujukkan bahwa makin banyak pakan yang dimanfaatkan oleh ternak.

Susanti, dkk (2019), menyatakan bahwa pemberian pakan komplit memiliki konversi pakan lebih rendah dikarenakan kandungan dan komposisi nutrisi pakan komplit disusun berdasarkan standar kebutuhan. Semakin dewasa ayam maka nilai konversi pakan semakin besar. Angka konversi pakan yang kecil berarti jumlah pakan yang digunakan untuk menghasilkan satu kilogram daging semakin sedikit sedangkan semakin tinggi konversi pakan maka semakin boros pakan yang digunakan (Fadilah, 2007). Hal ini desebabkan nilai konversi pakan diperlukan untuk menggambarkan sejauh mana efektivitas biologis pemanfaatan zat gizi dalam pakan. Semakin kecil jumlah pakan yang dibutuhkan untuk menghasilkan pertambahan bobot badan ayam, berarti semakin efesien pemberian pakan tersebut. Pertambahan bobot badan merupakan tolak ukur yang memberi gambaran yang jelas mengenai pertumbuhan.

\section{Kesesuaian Kualitas Pakan Mitra Berdasarkan Hasil Analisis Laboratorium}

Dari hasil analisis laboratorium tentang jenis-jenis pakan yang digunakan pada peternakan mitra, bahwa ditemukan kadar air, kadar abu, serat kasar, dan lemak kasar yang telah memenuhi standar, sedangkan protein kasar terdapat perbedaan.

Kadar air dalam pakan sangat penting untuk diketahui dikarenakan kadar air akan mempengaruhi kualitas pakan selama penyimpanan. Kadar air yang melebihi standar dapat menyebabkan terjadinya proses pembusukan lebih cepat. Kadar air pakan komplit yang tertera di leaflet dibandingkan dengan standar SNI dan hasil analisis laboratorium disajikan pada Gambar 1.

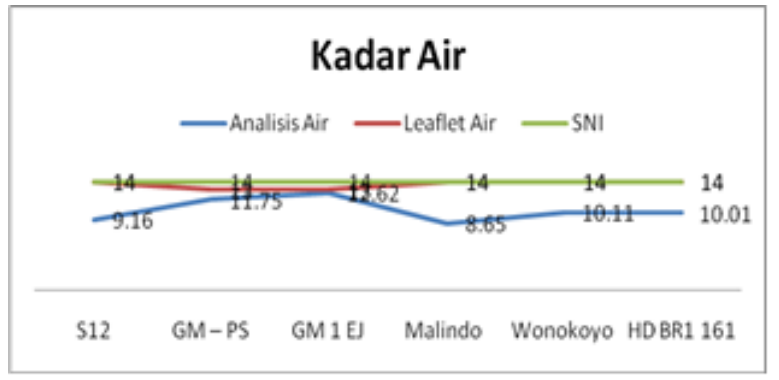

Gambar 1. Kadar air di leaflet, hasil analisis dan standar kebutuhan.

Nampak pada Gambar 1. Kadar air pakan komplit (leaflet) berkisar 13-14\% atau ratarata $13,6 \%$, sedangkan kadar air (analisis) berkisar 8,65-12,62\% atau rata-rata 10,38\%. Kadar air analisis lebih rendah 3,22\% dari yang tertera di leaflet. Penurunan kadar air disebabkan oleh suhu pada lingkungan dan proses penyimpanan serta lama penyimpanan. Di samping itu kadar air seluruh pakan masih memenuhi standar mutu pakan yaitu maksimal 14\% (SNI, 2015), 
semakin sedikit kadar air pakan maka akan semakin baik kualitas pakan tersebut dan semakin lama daya simpannya karena jamur akan sulit untuk berkembang. Kandungan air yang berlebihan dalam pakan akan mempengaruhi kandungan nutrien pakan, dimana air yang terkandung dalam pakan akan memicu tumbuhnya jamur, bakteri dan mikroorganisme lainnya untuk berkembang. Bakteri, jamur dan mikroorganisme berpotensi mempercepat terjadinya penurunan kandungan nutrien pakan. Namun demikian kandungan air dalam pakan akan berpengaruh juga terhadap daya cerna ayam dan tingkat konsumsi pakan. Semakin tinggi daya cerna ayam terhadap pakan yang diberikan maka akan berpengaruh terhadap tingkat konsumsi pakan oleh ayam (Nasruddin, 2010).

Kadar abu merupakan sisa zat anorganik hasil pembakaran bahan organik. Kadar abu merupakan salah satu parameter dalam penentuan kandungan gizi pakan karena kadar abu dapat menggambarkan kandungan mineral suatu bahan pakan (Lestari, 2014). Perhitungan kadar abu bertujuan untuk mengetahui baik tidaknya suatu pakan, membedakan makanan asli dan sintesis serta sebagai parameter suatu bahan (Irawati, 2008). Kadar abu pakan komplit yang tertera di leaflet dibandingkan dengan standar SNI dan hasil analisis laboratorium disajikan pada Gambar 2.

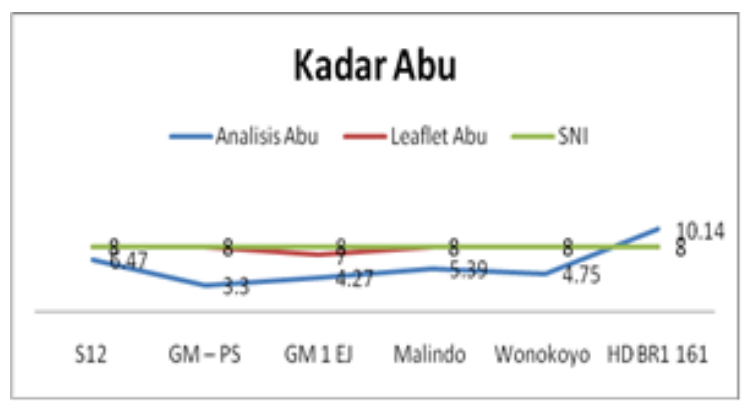

Gambar 2. Kadar abu di leaflet, hasil analisis dan standar kebutuhan.

Pada Gambar 2. Kadar abu pakan komplit (leaflet) berkisar 7-8\% atau rata-rata 7,8\%, sedangkan kadar abu (analisis) berkisar 3,3-10,14\% atau rata-rata 5,72\%. Kadar abu analisis lebih rendah 2,08\% dari yang tertera di leaflet. Kadar abu merupakan mineral sisa pembakaran yang ikut terbakar secara sempurna (Nasruddin, 2010). Menurut standar kebutuhan SNI 2015, kadar abu pakan komplit yaitu maksimal $8 \%$ yang artinya kadar abu pakan yang digunakan oleh peternak mitra memenuhi standar kebutuhan ayam broiler.

Kadar protein merupakan salah satu nutrien yang paling penting dalam pakan yang berguna untuk meningkatkan percepatan pertumbuhan dan produksi terutama untuk peningkatan produksi ayam pedaging (Nasruddin, 2010). Protein kasar pakan komplit yang tertera di leaflet dibandingkan dengan standar kebutuhan (SNI 2015) dan hasil analisis laboratorium disajikan pada Gambar 3. 


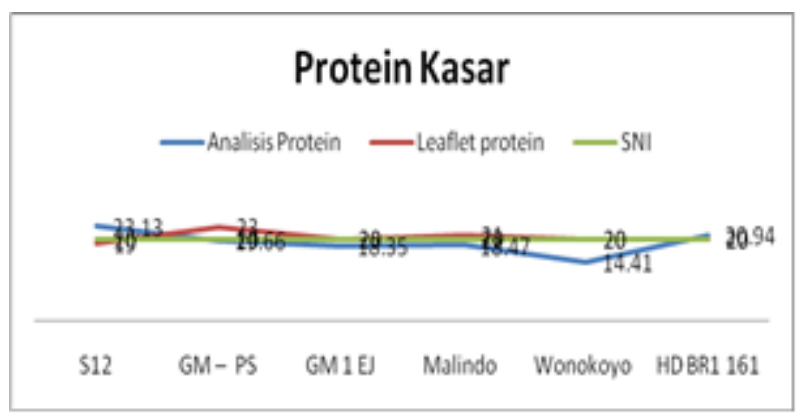

Gambar 3. Kadar protein di leaflet, hasil analisis dan standar kebutuhan.

Pada Gambar 3, kadar protein pakan komplit (leaflet) 20,17\%, sedangkan kadar protein (analisis) berkisar 14,41-23,13\% atau rata-rata 19,16\%. Standar kebutuhan protein broiler yaitu minimal 20\% (SNI, 2015). Terdapat beberapa pakan komplit yang kadar proteinnya lebih rendah dari yang tertera di leaflet dan standar kebutuhan, kemungkinan disebabkan perjalanan pakan yang panjang dari pabrik pusat ke peternak dengan proses penyimpanan yang tidak memenuhi standar, tidak dipungkiri akan adanya aktifitas mikroorganisme yang merusak pakan. Sesuai pernyataan Winarno (1983), mikroorganisme akan mendegradasi pakan menjadi fraksi-fraksi yang lebih kecil, menghasilkan asam yang menyebabkan penurunan $\mathrm{pH}$ dan terbentuknya gas yang dapat mempengaruhi bau dan cita rasa. Penurunan kadar protein kasar juga dipengauhi oleh jenis kemasan dan lama penyimpanan. Hal ini sesuai dengan pendapat Dwinarto, dkk. (2018) yang menyatakan, penurunan kadar protein pada pakan dapat disebabkan oleh faktor kondisi plastik seal yang tidak kedap oleh udara, transparan yang dapat mengakibatkan nilai nutrien protein kasar mengalami penurunan karena terjadi proses enzimatis. Selain itu waktu penyimpanan yang lebih lama akan menyebabkan kerusakan yang lebih besar karena adanya reaksi dengan sinar cahaya yang akan meningkatkan suhu dan juga udara yang menyebabkan peningkatan kadar air, dimana kadar air akan bereaksi dengan enzim yang mengakibatkan terjadinya proses enzimatis yang mendenaturasi protein.

Lemak kasar merupakan semua senyawa dalam pakan yang larut dalam pelarut organik, antara lain ether, petroleum dan cloroform (Angelina, 2019). Lemak berfungsi sebagai pemasok energi bagi tubuh, sehingga kadar lemak dalam pakan harus diperhatikan karena dapat mempengaruhi kondisi ternak, status fisiologis dan produksi. Kadar lemak kasar pakan komplit yang tertera di leaflet dibandingkan dengan standar SNI dan hasil analisis laboratorium disajikan pada Gambar 4.

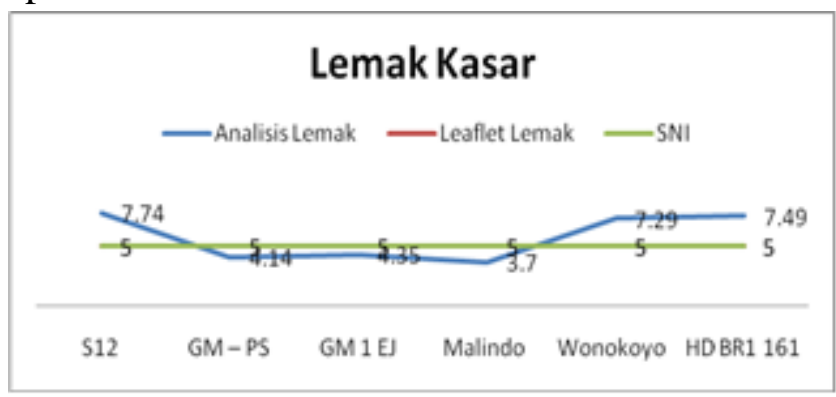

Gambar 4. Kadar lemak di leaflet, hasil analisis dan standar kebutuhan. 
Pada Gambar 4. Kadar lemak pakan komplit (leaflet) berkisar 5\%, sedangkan kadar lemak (analisis) berkisar 3,7-7,74\% atau rata-rata 5,79\%. Kadar lemak analisis lebih tinggi $0,79 \%$ dari yang tertera di leaflet. Kadar lemak yang berlebihan dapat menyebabkan ketengikan serta kerusakan pada pakan dan daya simpan pakan menjadi tidak lama. Kebutuhan nutrien ayam pedaging lemak kasar yaitu minimal 5\%- 8\%. Jadi kandungan lemak kasar pada semua pakan komplit yang digunakan oleh peternak mitra masih dalam batas wajar. Gunawan dan Tangenjaya (1989), mengemukakan bahwa kadar asam lemak dapat semakin meningkat seiring dengan bertambahnya waktu penyimpanan.

Serat kasar terdiri dari selulosa, hemiselulosa dan lignin yang sebagian besar tidak dapat dicerna unggas dan bersifat sebagai pengganjal atau bulky. Pencernaan serat kasar di unggas terjadi pada caecum dengan bantuan mikroorganisme yang disebabkan unggas tidak memiliki enzim selulase yang dapat memecah serat kasar (Wahju, 2004). Daya cerna serat kasar pada unggas dipengaruhi oleh kadar serat pakan dan aktifitas mikroorganisme (Nonok dan Eka, 2011). Kadar serat kasar pakan komplit yang tertera di leaflet dibandingkan dengan standar SNI dan hasil analisis laboratorium disajikan pada Gambar 5.

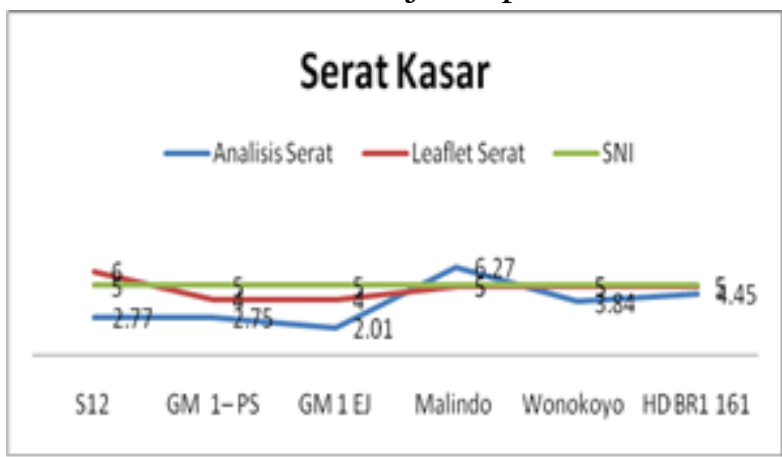

Gambar 5. Kadar Serat Tertera leaflet, Hasil Analisis dan Standar Kebutuhan.

Pada Gambar 5. kadar serat pakan komplit (leaflet) berkisar 4-5\% atau rata-rata 4,6\%, sedangkan kadar serat kasar (analisis) berkisar 2,01-6,27\% atau rata-rata 3,68\%. Kadar serat kasar analisis lebih rendah $0,92 \%$ dari yang tertera di leaflet. Serat kasar pada pakan berfungsi untuk membantu gerak peristaltik usus, mencegah penggumpalan pakan pada seka, mempercepat laju digesta dan memacu perkembangan organ pencernaan. Kadar serat yang sesuai akan memaksimalkan ayam dalam menerima nutrien (Angelina, 2019). Kadar serat kasar pada pakan komplit yang digunakan oleh peternak mitra masih memenuhi standar kebutuhan nutrien ayam pedaging yaitu minimal 5\% (SNI, 2015).

\section{KESIMPULAN DAN SARAN}

\section{Kesimpulan}

Produktifitas ayam pedaging pada peternakan mitra di kabupaten Lombok Barat berdasarkan indikator konsumsi pakan, bobot panen, dan FCR masih memenuhi standar yang ditetapkan oleh perusahaan, hal ini dikarenakan kualitas pakan yang digunakan masih memenuhi standar walaupun pada beberapa pakan kadar protein lebih rendah dari standar minimal. 


\section{Saran}

Evaluasi Kualitas Pakan Dan Produktifitas Ayam Pedaging Pada Peternakan Mitra Harus Dilakukan Secara Berkala Agar Peternak Mendapat perlindungan dan keuntungan yang maksimal.

\section{DAFTAR PUSTAKA}

Adventa, E., 2019. Peluang Ternak Ayam Mitra Japfa Comfeed. https://peluangusaha.kontan.co.id. (23 Februari 2020).

Amrulah, I. K . 2004. Nutrisi Ayam Pedaging. Cetakan Ketiga. Lembaga Satu Gunung Budi, Bogor.

Anggelina, B. S. 2019. Analisis Kandungan Proksimat Pakan Organik Yang Diberi Suplemen Probiotik H dan pengaruhnya Terhadap Berat Badan Ayam Bangkok. Skripsi. Fakultas Keguran dan Ilmu Pendidikan, Yogyakarta.

Anggitasari,S.,Sjofjan, O., dan Djunaidi, I. H. 2016. Pengaruh Beberapa Jenis Pakan Komersial Terhadap Kinerja Produksi Kuantitatif dan Kualitatif Ayam Pedaging. Buletin Peternakan Vol. 40 (3): 187-196.

Antara, M. dan B. Aji, 2020. Strategi Pemasaran Ayam Broiler Pada PT.Mitra Sinar Jaya Denpasar. dwijenAGRO Vol. 1 No. 2.

AOAC. 1990. Official Methods of Analysis. Washington DC: Association of the Official Agricultural Chemists.

Bahri, S. dan Rusdi. 2008. Evaluasi Energi Metabolis Pakan Lokal Pada Ayam Petelur. J. Agroland 15 (1): 75 - 78.

Direktorat Pembinaan SMK Kemendikbud RI, 2013. Dasar-dasar Pemeliharaan Ternak. Buku Teks Bahan Ajar Siswa. Kemendikbud RI.

Dwinarto, B., Haryanti, D., Utomo, S. 2018. Pengaruh Jenis Kemasan dan Waktu Penyimpanan Pada Pakan Broiler Starter Terhadap Kadar Air dan Protein Kasar. ISSN : 2252-7311, Vol 7 No 2.

Fadilah, R., 2007. Beternak Unggas Bebas Flu Burung. Agromedia Pustaka. Jakarta.

Fatmaningsih, R., Riyanti, \&Nova, K. (2016). Performa Ayam Pedaging pada Sistem Brooding Konvensional dan Thermos.Jurnal Ilmu Peternakan, 4 (3), 222-229.

Fitro, R., Sudrajat, D., \& Dihansih, E. (2015). Peforma Ayam Pedaging yang diberi Ransum

Komersial Mengandung Tepung Ampas Kurma sebagai Pengganti Jagung. Jurnal Peternkan Nusantara, 1(1), 1-8.

Gunawan dan B. Tangendjaja. 1989. Pengaruh Kadar Asam Lemak Bebas dalam Ransum Terhadap Pertumbuhan Ayam Pedaging. Ilmu dan Peternakan 2 (4): 159 - 162.

Gunawan. dan Sihombing (2004). Pengaruh Suhu Lingkungan Tinggi Terhadap Kondisi Fisiologis dan Produktivitas Ayam Buras.Jurnal Wartazoa, 14 (1), 31-38

Irawati. 2008. Modul Pengujian Mutu1.Diploma IV PDPPTK Vedca.Cianjur.

Izkey, 2018. 6 Kerugian dan Keuntungan Ternak Ayam Broiler Sistem Kemitraan. https://izkey.com. (23 Februari 2019). 
Lestari. 2014. Kandungan Zat Gizi Makanan Khas Yogyakarta.Gadjah Mada University Press. Yogyakarta.

Medion, 2014. Mengenal Ransum Ayam. www.info.medion.co.id. (15 April 2015).

Nasruddin. 2010. Komposisi Nutrien Pakan Ayam Ras Pedaging (Broiler Finisher) dari Beberapa Bahan Pakan Lokal. Dinamika Penelitian BIPA Vol. 21 No. 38.

Nonok dan Eka. 2011. Penggunaan Bekatul Vermentasi "Aspergullus Niger" Dalam Pakan Terhadap Karakteristik Organ Dalam Ayam Pedaging. Buana Sains Vol 11 No 2: 127-136.

Purnamasari, D.K., Erwan., Syamsuhaidi., dan Kurniawan, M. 2016. Evaluasi Kualitas pakan komplit dan Konsentrat Unggas yang Diperdagangkan di Kota Mataram. Jurnal Peternakan Sriwijaya / Vol. 5, No. 1, 2016, pp. 30 - 38.

Rahardjo, Y. 2018. Beternak Ayam Petelur.Cetakan ke II. Penerbit Nuansa Cendekia. Bandung.

Rasyaf, 1993. .Beternak Ayam Petelur. PT. Penebar Swadaya Jakarta.

Saguni, A.W., 2010. Analisa Pendapatan Peternak ayam Potong Sistem Kemitraan Di Keecamatan turen Kabupaten Malang. https://www.researchgate.net. (23 Februari 2019)

Resnawati, H. 2006. Retensi Nitrogen dan Energi Metabolis Ransum Yang Mengandung Cacing Tanah Pada Ayam Pedaging. Seeminar Nasional Teknologi Peteranakan dan Veteriner. Bogor.

Standar Nasional Indonesia (SNI). 2015. leaflet Pakan Ayam Ras Pedaging (Broiler). respository.pertanian.go.id (10 Agustus 2020)

Susanti, F., Ichsan, M., \& Haryani, N. (2019). Peformans Ayam Broiler yang Diberikan Ransum Berbasis Jagung Fermentasi. Jurnal Ilmu dan Teknologi Peternakan Indonesia, 5 (1), 51-59.

Tamalludin, F. 2014. Panduan Lengkap Ayam Broiler. jakarta: Penebar Swadaya.

Wahju J. 1998. Ilmu Nutrien Unggas Cetakan ke 3.Gadjah Mada University Press.Yogyakarta. 2004. Ilmu Nutrien Unggas Cetakan ke 5. Gadjah Mada University Press. Yogyakarta.

Widodo, W. 2009. Nutrisi dan Pakan Unggas Kontekstual.Universitas Muhammadiyah Malang, Malang.

Winarno, F.G. 1983. Kerusakan Bahan Pakan dan Cara Penanggulangannya. Jakarta: Ghalia Indonesia. 